\title{
COMPARISON OF MERCURY RETENTION BY FLY ASHES USING DIFFERENT EXPERIMENTAL DEVICES
}

\author{
M. Antonia López-Antón ${ }^{a}{ }^{*}$, Patricia Abad-Valle ${ }^{b}$, Mercedes Díaz-Somoano ${ }^{b}$, \\ Ron Perry ${ }^{a}$, Colin E. Snape ${ }^{a}$ Cheng-gong Sun ${ }^{a}$ and M. Rosa Martínez-Tarazona ${ }^{b}$ \\ ${ }^{a}$ Fuels and Power Technology Research Division, Faculty of Engineering, University \\ Park, University of Nottingham, Nottingham, NG7 2RD, United Kingdom \\ ${ }^{b}$ Instituto Nacional del Carbón (CSIC). C/ Francisco Pintado Fe No 26, 33011, Oviedo, \\ Spain
}

*Corresponding author

Phone: $+44(0) 1159514198$

Fax: $\quad+44(0) 1159514115$

e-mail: marian.lopez-anton@,nottingham.ac.uk 


\begin{abstract}
In order to study mercury $(\mathrm{Hg})$ retention in solid sorbents, researchers generally employ similar laboratory scale devices. However, despite their similarities, these devices are generally used under different experimental conditions. The $\mathrm{Hg}$ concentration in gas phase, gas flow and sorbent bed characteristics are variables that influence the contact time, mass transfer and kinetics and may greatly modify the quantities of $\mathrm{Hg}$ retained when the same sorbents are compared. These differences in the experimental conditions do not impede an evaluation of the sorbents as long as the results obtained points towards the same qualitative conclusions. However, the extent of variation needs to be defined to avoid misleading. To illustrate the range of interpretations, the results of a preliminary approach using four experimental devices in two laboratories have been compared in this work. All the experiments were carried out under a nitrogen atmosphere and $\mathrm{Hg}^{0}$ in gas phase. The same sorbents were employed in all the devices. These were fly ashes obtained from the combustion of coals of different rank and with different unburned carbon contents. From the results obtained it can be inferred that it is necessary to strictly control the influence of the experimental variables in order to infer a correct interpretation of the results.
\end{abstract}

Keywords: mercury; fly ash; coal combustion 


\section{Introduction}

Mercury $(\mathrm{Hg})$ emissions are a global air pollution problem that is attracting significant attention worldwide. Of all the sources of anthropogenic $\mathrm{Hg}$ emissions, coal combustion has been reported to be the largest single category ${ }^{1-3}$. Estimations of the contributions to total emissions in Europe indicated that in $200438 \%$ of anthropogenic mercury emissions originated from coal combustion ${ }^{4}$. As a consequence, legislative bodies in Europe and USA have considered reducing $\mathrm{Hg}$ emissions from coal fired power plants ${ }^{2-5}$. A ruling to regulate $\mathrm{Hg}$ emissions from coal fired power plants was announced in USA in line with the Clean Air Act of March 15, $2005^{6}$. Although the Federal regulatory structure for $\mathrm{Hg}$ emissions from coal-fired power plants is once again uncertain following the vacatur of EPA`s Clean Air Mercury Rule on February 8, 2008 ${ }^{7}$, the U.S. Environmental Protection Agency (EPA) in collaboration with public-private research organizations have fostered the development of a suite of mercury control technologies for coal-fired power plants ${ }^{8}$.

In this situation a number of research groups have focused their research activity on evaluating different solid sorbents to capture mercury species in flue gases from coal combustion employing laboratory scale devices ${ }^{9-28}$. These laboratory devices are mainly based on fixed sorbent beds. Although the quantitative results obtained from these devices are different to those expected at industrial scale, they provide a good method for checking the ability of a given solid material to capture mercury and, what is more important, a means of comparing the behaviors of different sorbents in order to be able select the most appropriate. 
In the studies carried out using sorbent bed reactors, the experimental conditions are usually very different. The $\mathrm{Hg}$ concentrations in flue gases emitted during coal combustion in a power station can reach values ranging from 30 to $70 \mu \mathrm{g} / \mathrm{m}^{310,22}$. In the laboratory tests ${ }^{23-25}$ concentrations of $\mathrm{Hg}$ ranging from 10 to $11.7 \times 10^{3} \mu \mathrm{g} / \mathrm{m}^{3}$ have been examined. The flue gas rates of the sorbent used in laboratory scale studies have varied between 0.030 and $15 \mathrm{~L} / \mathrm{min}^{20-21,26-27}$ while the temperatures have ranged from 100 to $177{ }^{\circ} \mathrm{C}^{24-25,} 28$ similar to the temperatures around electrostatic precipitators and scrubbers. Because Hg retention may be significantly influenced by these parameters, this work tries to asses the effects of the experimental conditions on $\mathrm{Hg}$ retention in order to select the best conditions. This assessment will help to explain apparently conflicting results and lead to a better understanding of the behavior of sorbents in $\mathrm{Hg}$ capture. Although an accurate evaluation of the variables affecting laboratory scale reactors needs to be modeled, an approximate description of the range of conditions to be compared is necessary. The aim of this paper is to discuss the results and their possible interpretations using four experimental devices in two laboratories with various fly ashes as sorbents. The experiments were carried out in a nitrogen atmosphere using $\mathrm{Hg}^{0}$ in gas phase. The fly ashes were well characterized previously ${ }^{20-21,29}$. It should be emphasized that the aim of the work is not to evaluate the fly ash characteristics as sorbents, but to ascertain the reliability of the results when different laboratory scale reactors are used.

\section{Experimental}

Four fly ash samples were employed in this study, three of which were obtained from pulverized coal combustion power plants (PCC), while the fourth was taken from a fluidized coal combustion power plant $(\mathrm{FBC})$ that uses limestone in its bed. In one of 
the power stations the blend contained high rank coals (CTA). In another, high volatile bituminous coals were used (CTSR), while in the third, sub bituminous coals were burned (CTES). The FBC plant was fed with a blend of bituminous coal and coal wastes of high calorific value. This sample was denoted CTP. Different size fractions were separated from each sample in order to obtain samples enriched in unburned carbon $(\mathrm{CTA}>150 \mu \mathrm{m}, \mathrm{CTSR}>80 \mu \mathrm{m}$ and CTES $>200 \mu \mathrm{m})$. In the CTP sample, the unburned carbon was homogeneously distributed amongst the different size fractions and for this reason only the raw CTP sample was used in this study. The average of particle size for the raw fly ashes ranged from 10 to $60 \mu \mathrm{m}$ being 321,175 and $270 \mu \mathrm{m}$ for the fractions CTA $>150$, CTSR $>80$ and CTES $>200$, respectively. The unburned carbon content in each size fraction was estimated as loss of ignition (LOI) at $815^{\circ} \mathrm{C}$, and the BET surface area was measured by means of volumetric adsorption of nitrogen at $77 \mathrm{~K}$. In previous studies on CTA, CTP, CTSR, CTES fly ashes ${ }^{20-21,29}$ it was concluded that mineral matter differences had no affect on mercury adsorption capacity. However, mercury capture is influenced by the carbon content in the samples enriched in unburned carbon, and the mercury retention capacity was found to be higher in the fly ashes obtained from bituminous coals.

The laboratory devices used for $\mathrm{Hg}$ retention are shown in Figures 1-4, and the experimental conditions used are listed in Table 1. The experimental devices used for the retention experiments consisted of glass reactors heater by furnaces and fitter with a thermocouple. The gas lines were heated to avoid possible condensations. All the experiments were carried out under a $\mathrm{N}_{2}$ atmosphere. The temperature of the sorbent was maintained at $120^{\circ} \mathrm{C}$ in all cases. The sorbent bed was prepared by mixing the fly ash sample with sand in different proportions (Table 1). The dimensions of the sorbent bed in each reactor were different (Figure 1). 
Experimental device $\mathrm{N}^{\mathrm{o}} 1$ (Figures 1-2, Table 1) included a glass reactor fitted with an internal and external tube and heated by two different furnaces. In this device $\mathrm{Hg}$ in gas phase was obtained by evaporating $\mathrm{Hg}^{0}$. The fly ash bed and the element source were placed inside the same internal tube but heated separately in the two furnaces. The $\mathrm{Hg}$ that could not be retained in the sorbent bed was captured by impingers containing $1 \mathrm{~N} \mathrm{KCl}, 5 \% \mathrm{HNO}_{3} / 10 \% \mathrm{H}_{2} \mathrm{O}_{2}$ and $4 \% \mathrm{KMnO}_{4} / 10 \% \mathrm{H}_{2} \mathrm{SO}_{4}$. The amount of $\mathrm{Hg}$ retained was determined by analyzing the fly ashes post-retention in a cold vapor atomic absorption spectrometer (CV-AAS) after extraction using $60 \%(\mathrm{v} / \mathrm{v})$ $\mathrm{HNO}_{3}$. The $\mathrm{Hg}$ concentration in gas phase was greater than it is in power stations (Table $1)$.

Reactor $\mathrm{N}^{\circ} 2$ (Figures 1 and 3) was similar to the one described above but in this case the $\mathrm{Hg}$ in gas phase was produced outside the reactor using a permeation tube. The concentration of $\mathrm{Hg}$ passed through this reactor was much lower and similar to that expected in a power station $\left(19.8 \mu \mathrm{g} / \mathrm{m}^{3}\right)$ (Table 1). A continuous $\mathrm{Hg}$ emission monitor (UT 3000) was used to monitor the $\mathrm{Hg}$ and to obtain $\mathrm{Hg}$ adsorption curves. As in the case of the react $\mathrm{N}^{\circ} 1$, any $\mathrm{Hg}$ that could not be retained in the sorbent bed was captured by impingers containing the same solutions as in the first reactor.

In experimental device $\mathrm{N}^{\mathrm{o}} 3$ (Figures 1 and 4) was possible to observe the effect of using a much lower gas flow than in reactors $\mathrm{N}^{\circ} 1$ and $\mathrm{N}^{\circ} 2$ (Table 1). In this case, the saturated $\mathrm{Hg}$ vapor was made to pass from a bottle to the sample tube containing the sorbent and then via through a 3-way valve to a flow-through cell in the UV beam of an atomic absorption spectrometer (AAS), operating in cold vapor mode.

Finally, device $\mathrm{N}^{\mathrm{o}} 4$ was designed to resemble $\mathrm{N}^{\mathrm{2}} 2$ but was equipped with a different reactor and consequently had a different sorbent bed volume and bed 
characteristics (Figure 1). In device $\mathrm{N}^{\mathrm{o}} 4$ the nitrogen sweep gas rate was lower than in No2 (Table 1).

\section{Results and discussion}

Although the influence of LOI and BET surface area on mercury retention has been studied in a previous work ${ }^{20}$ the data are included in this paper (Table 2 ) in order to illustrate the key differences between the fly ash samples. Retention capacity is defined as the amount of $\mathrm{Hg}$ retained per $\mathrm{g}$ of fly ash and the confidence limits of the results are represented by the standard deviations (Table 3). It was considered that equilibrium uptake would be reached when the outlet concentration became equal to the inlet concentration. Equilibrium or maximum retention capacity (MRC) was achieved in all cases, except for the CTSR $>80$ sample in reactor $\mathrm{N}^{\circ} 4$, in which MRC was not achieved even after 18 hours. In Figure 5 examples of the breakthrough curves are presented as the ratio of the outlet to the inlet concentration $\left(\mathrm{C}_{\text {out }} / \mathrm{C}_{\text {in }}\right)$ versus time for the four experimental devices. For experimental device $\mathrm{N}^{\mathrm{o}} 1$, the breakthrough curve is discontinuous because the $\mathrm{Hg}$ retained was determined by analyzing the sorbent postretention after different amounts of elemental $\mathrm{Hg}$ had been passed through the sorbent bed.

The results in Table 3 shows that $\mathrm{Hg}$ retention by the four fly ashes and the three fly ash carbon concentrates is different in the four experimental conditions used (Table 1). This is not surprising but what needs to be established is whether in all the experimental devices the results show the same trend when the sorbent behaviors are compared. It was already known that the retention capacities of all these samples are 
influenced not only by the experimental conditions but also by the characteristics of the samples. If the results obtained with the original fly ashes (CTA, CTP, CTSR, CTES) from all the experimental devices are compared, it may be concluded that CTSR is the best fly ash for mercury capture (Figure 6). However, when mercury retention in CTP, CTA and CTES is compared, a different picture emerges because the trend in the behavior of these samples varies slightly depending on the experimental conditions. Thus, mercury retention capacity can be arranged in increasing order as $\mathrm{CTP}>\mathrm{CTA}>\mathrm{CTES}$ in reactor 1 and 4 , whereas in reactors 2 and 3, in which the retention capacities are lower, not significant differences can be observed between the three fly ashes. When the unburned carbon concentrates (CTA>150, CTSR $>80$ and CTES $>200)$, that have a higher mercury retention capacity than the original fly ashes, are compared, the best sorbent is CTSR $>80$. This is followed by CTES $>200$ and CTA $>150$ for all the devices (Figure 6), the only exception being in device $\mathrm{N}^{\mathrm{o}} 1$ (Table 3 ). It can be conclude that for the samples with the highest retention capacity, the trend observed in all cases is similar and consequently the conclusion will be the same. However, the evaluation of the sorbents with a low retention capacity may be misleading if the experimental conditions are not clearly defined.

As might be expected, increasing the $\mathrm{Hg}$ concentration in gas phase, which influences mass transfer, enhances $\mathrm{Hg}$ capture (Figure 7). However, the greater retention capacity due to the huge differences in the mercury concentrations in gas phase is not the only effective way to differentiate the mercury retention capacities trend of some of the samples. This is demonstrated if we consider the results obtained in the devices using the highest mercury concentration in gas phase $\left(\mathrm{N}^{\circ} 1\right.$ and $\left.\mathrm{N}^{\circ} 3\right)$ (Table 3$)$. In reactor $\mathrm{N}^{\mathrm{o}} 1$ it is not possible to differentiate between the fly ash and its unburned carbon concentrates and in $\mathrm{N}^{\circ} 3$ it is not possible to differentiate among the four original 
fly ashes. Neither is it possible for most of the samples in reactor $\mathrm{N}^{\mathrm{o}} 2$, which used the lowest mercury concentration in gas phase and the highest flue gas rate. However, the results obtained in reactor $\mathrm{N}^{\circ} 4$ reveal different mercury retention capacities for different types of fly ashes which may serve as basis of comparison.

$\mathrm{Hg}$ contact time is another important factor that influences retention. If we compare the results from reactors $\mathrm{N}^{\circ} 2$ and $\mathrm{N}^{\circ} 4$ where $\mathrm{Hg}$ contact time is the same (Table 1), similar retention capacities can be observe (Table 3). In these two cases, the times needed to achieve the equilibrium capacity were similar (Tables 1 and 3). The highest retention was achieved in device $\mathrm{N}^{\mathrm{o}} 1$, where the $\mathrm{Hg}$ in gas phase was one order of magnitude higher than in $\mathrm{N}^{\mathrm{3}} 3$ and the quantity of $\mathrm{Hg}$ passing through the bed per minute was much greater (Table 1). This was found to have a considerable effect on the retention of $\mathrm{Hg}$ in all the fly ashes studied but especially in the case of the CTSR fly ash which was able to retain more than $3 \mathrm{mg}$ of $\mathrm{Hg}$ per $\mathrm{g}$ of fly ash in reactor $\mathrm{N}^{\mathrm{o}} 1$. In this fly ash, which exhibits the greatest retention, the differences between the retention by the raw fly ash CTSR and the fly ash fraction with a high concentration of unburned particles $($ CTSR $>80)$ are very small. A similar situation is observed in CTA.

Although for the purposes of this study we have used fly ash samples and their fractions enriched in unburned carbon, the effect of the carbon particles on the retention of $\mathrm{Hg}$ is not discussed as this matter has been dealt with in previous papers ${ }^{18,28}$. However we will use the results obtained from these papers to support our interpretation when discussing the different reactors. It should be noted that the differences in retention capacities between a given fly ash and its fraction concentrated in unburned particles cannot be clearly elucidated in all cases in the conditions of devices $\mathrm{N}^{\circ} 1$ and $\mathrm{N}^{\mathrm{o}} 2$ (Figure 8 ). By contrast, the positive effect of a high quantity of unburned particles 
in fly ashes on $\mathrm{Hg}$ retention (high LOI and surface area) (Table 2), is clearly demonstrated in most of the other conditions employed.

Although a relationship between the flue gas rate and $\mathrm{Hg}$ retention capacity cannot be inferred (Figure 9), a comparison of the results from the reactors that have high $\mathrm{Hg}$ concentrations ( $\mathrm{N}^{\mathrm{o}} 1$ and 3 ) with those that have low concentrations in gas phase ( $\mathrm{N}^{\circ} 2$ and 4) shows that a decreasing flow rate $\left(\mathrm{N}^{\circ} 3\right.$ and 4$)$ may favor retention in unburned coal particles (Table 3).

Other factors that may influence mercury capture are linked to the characteristics of the sorbent bed illustrated in Figure 1 and Table 1. If the results from the reactors that employ low $\mathrm{Hg}$ concentrations in gas phase ( $\mathrm{N}^{\circ} 2$ and 4) are compared $\mathrm{Hg}$ retention might be expected to be favored in the device $\mathrm{N}^{\circ} 4$ (Figure 1) and indeed, the $\mathrm{Hg}$ retention capacities in the fly ash carbon concentrates are higher in reactor $\mathrm{N}^{\mathrm{o}} 4$ than in $\mathrm{N}^{0} 2$ (Table 3). In the case of reactors using high $\mathrm{Hg}$ concentrations $\left(\mathrm{N}^{\circ} 1\right.$ and $\left.\mathrm{N}^{\circ} 3\right)$, it is the longer $\mathrm{Hg}$ contact time and the higher $\mathrm{Hg}$ concentration in gas phase (Table 1) that seems to influence $\mathrm{Hg}$ capture rather than the dimensions of the reactor (Figure 1), especially in the case of the CTSR samples.

In summary, a higher $\mathrm{Hg}$ concentration in gas phase leads to a greater $\mathrm{Hg}$ retention (i.e. for reactors $\mathrm{N}^{0} 1$ and 3 ) and in most cases the time necessary to achieve the equilibrium capacity is shorter. But at high flue gas rates $\left(\mathrm{N}^{\circ} 1\right)$ the influence of the unburned carbon in the fly ashes is not clearly discernible. In the reactors with low $\mathrm{Hg}$ concentration in gas phases (i.e. for reactors $\mathrm{N}^{\circ} 2$ and 4), the influence of the unburned carbon is again discernible in reactor with the lowest flue gas rate $\left(\mathrm{N}^{\circ} 4\right)$.

Although the fly ashes generally follow the same trend in the four reactors studied, the differences between reactors may give rise an erroneous interpretation of the results. The conditions in reactor $\mathrm{N}^{\mathrm{o}} 4$ seem to be the most appropriate for studying 
mercury retention capacities in fly ashes. Future work on the optimization and modeling of experimental devices could be based on similar conditions to those tested in this device, i.e. mercury concentrations in the simulated gas of the order of $100 \mu \mathrm{g} \mathrm{Hg} \mathrm{m}^{-3}$ and a contact time, defined as $\mu \mathrm{g} \mathrm{Hg} \min ^{-1}$, of around 0.05 .

The evaluation of mercury retention by coal sub-products in a power station can be carried out at industrial scale. However, in order to understand the mechanisms governing this retention, laboratory scale studies are necessary. These laboratory scale studies need to be designed in such a way that the enormous effort being carried out by different research groups would be added. This work contributes to understand how we could compare results obtained in different systems.

\section{Acknowledgments}

The financial support for this work was provided by project CTM2004-04252.CO202/TECNO, by the Royal Society with provided a mobility grant for researchers and by the DTI Cleaner Coal Technology R\&D Programme (project 408).

\section{References}

(1) US EPA. A study of hazardous air pollution from electric utility steam generating units: final report to congress. EPA-453/R-98-004a, US EPA Office of Air Quality Planning and Standards. Washington DC: US Government Printing Office; February 1998. 
(2) US EPA. Mercury study report to congress. EPA-452/R-97-003, US EPA Office of Air Quality Planning and Standards. Washington DC: US Government Printing Office; December 1997.

(3) Commission of the European Communities. Commission staff working paper. Annex to the Communication from the Commission to the council and the European Parliament on Community Strategy Concerning Mercury Extended Impact Assessment $\operatorname{COM}(2005) 20$ final.

(4) The European Pollutant Emission Register (EPER) http://www.eper.cec.eu.int

(5) European Commission. Ambient air pollution by mercury Position paper; Office for official publications of the European Communities (KH-41-01-341-EN-N). ISBN 92894-2053-7, 2001.

(6) US EPA. Clean air mercury rule. Available from: http://www.epa.gov/mercuryrule; March 15, 2005.

(7) http://pacer.cadc.uscourts.gov/docs/common/opinions/200802/05-1097a.pdf.

(8) Feeley III, T. J.; Jones, A. P.; Brickett, L. A.; O`Palko, B. A.; Miller, C. E.; Murphy, J. T. An update on DOE's Phase II and Phase III mercury control technology R\&D program. Fuel Process. Technol. 2009 (in press).

(9) Pavlish, J. H.; Mann, M. D. A comparison of air toxic metal control technologies. Presented at the Air and Waste Management $91^{\text {st }}$ Annual Meeting and Exhibition, June 1998.

(10) Felsvang, K.; Gleiser, R.; Juip, G.; Nielsen, K. K. Activated carbon injection in spray dryer/ESP/FF for mercury and toxics control. Fuel Process. Technol. 1994, 39, 417. 
(11) Pavlish, J. H; Sondreal, E. A.; Mann, M. D.; Olson, E. S.; Galbreath, K. C.; Laudal, D. L.; Benson, S. A. Status review of mercury control options for coal-fired power plants. Fuel Proc. Technol. 2003, 82(2-3), 89.

(12) Skodras, G.; Diamantopoulou, Ir.; Zabaniotou, A.; Stavropoulos, G.; Sakellaropoulos, G. P. Enhanced mercury adsorption in activated carbons from biomass materials and waste tires. Fuel Proc. Technol. 2007, 88, 749.

(13) Alptekin, G. O.; Dubovik, M.; Cesario, M.; Gershanovich, Y. Non-carbon sorbents for mercury removal from flue gases. Powder Technology 2008, 180, 35.

(14) Wu, J.; Cao, Y.; Pan, W.; Shen, M.; Ren, J.; Du, Y.; He, P.; Wang, D.; Xu, J.; Wu, A.; Li, S.; Lu, P.; Pan, W. Evaluation of mercury sorbents in a lab-scale multiphase flow reactor, a pilot-scale slipstream reactor and full-scale power plant. Chem. Eng. Sci. 2008, 63, 782 .

(15) Lee, S.; Lee, J.; Keener, T. C. Novel sorbents for mercury emissions control from coal-fired power plants. J. Chinese Inst. Chem. Eng. 2008, 39, 137.

(16) Wu, S.; Ozaki, M.; Uddin, Md. A.; Sasaoka, E. Development of iron-based sorbents for $\mathrm{Hg}^{0}$ removal from coal derived fuel gas: Effect of hydrogen chloride. Fuel 2008, 87, 467.

(17) Granite, E. J.; Freeman, M. C.; Hargis, R. A.; O’Dowd, W. J.; Pennline, H. W. The thief process for mercury removal from flue gas. J. Environ. Manag. 2007, 84, 628. (18) Li, Y.; Murphy, P.; Wu, Ch. Removal of elemental mercury from simulated coalcombustion flue gas using a SiO2-TiO2 nanocomposite. Fuel Proc. Technol. 2008, 89, 567.

(19) Presto, A. A.; Granite, E. J. Noble metal catalysts for mercury oxidation in utility flue gas. Platinum Metals Rev. 2008, 52(3), 1-10 
(20) López-Antón, M. A.; Díaz-Somoano, M.; Martínez-Tarazona, M. R. Mercury retention by fly ashes from coal combustion: Influence of the unburned coal content. Ind. Eng. Chem. Res. 2007, 46, 927.

(21) López-Antón, M. A.; Díaz-Somoano, M.; Martínez-Tarazona, M. R. Retention of elemental mercury in fly ashes in different atmospheres. Energ. Fuel 2007, 21, 99.

(22) Lei, Ch.; Yufeng, D.; Yuqun, Zh.; Liguo, Y.; Liang, Zh.; Zianghua, Y.; Qiang, Y.; Yiman, J.; Xuchang, X. Mercury transformation across particulate control devices in six power plants of China: The co-effect of chlorine and ash composition. Fuel 2007, 86(4), 603.

(23) Galbreath, K. C.; Zygarlicke, C. J.; Toman, D. L. Mercury-chlorine-fly ash interactions in a coal combustion flue gas. Proceedings of the Air and Waste Management Association $91^{\text {st }}$ Annual Meeting and Exhibition, June 14-18, San Diego, CA, 1998

(24) Serre, S. D.; Silcox, G. D. Adsorption of elemental mercury on the residual carbon in coal fly ash. Ind. Eng. Chem. Res. 2000, 39, 1723.

(25) Maroto-Valer, M. M.; Zhang, Y.; Granite, E. J.; Tang, Z.; Pennline, H. W. Effect of porous structure and surface functionality on the mercury capacity of a fly ash carbon and its activated carbon. Fuel 2005, 84,105

(26) Norton, G. A.; Yang, H.; Brown, R. C.; Laudal, D. L.; Dunham, G. E.; Erjavec, J.; Okoh, J. M. Effects of fly ash on mercury oxidation during post combustion conditions. Final Report DOE Award No. DE-FG26-98FT40111 September 1, 1998 through November 30, 2001

(27) Granite, E. J.; Pennline, H. W.; Hargis, R. A. Novel sorbents for mercury removal from flue gas. Ind. Eng .Chem. Res. 2000, 39, 1020. 
(28) Yudovich, Ya. E.; Ketris, M. P. Mercury in coal: review. Part 2. Coal use and environmental problems. In. J. Coal Geology 2005, 62, 135.

(29) López-Antón, M. A.; Abad-Valle, P.; Díaz-Somoano, M.; Suárez-Ruiz, I.; Martínez-Tarazona, M. R. The influence of carbon particle type in fly ashes on mercury adsorption. Fuel 2009, 88, 1194. 
Table 1. Experimental parameters for the different experimental devices

\begin{tabular}{|c|c|c|c|c|}
\hline & $N^{0} 1$ & $\mathbf{N}^{\circ} 2$ & $\mathbf{N}^{\mathbf{0} 3}$ & $N^{0} 4$ \\
\hline $\mathrm{Hg}$ concentration in gas phase, $\mu \mathrm{g} \mathrm{m}^{-3}$ & $410^{5}$ & 19.8 & $510^{4}$ & 99 \\
\hline Flue gas rate, $\mathrm{L} \mathrm{min}^{-1}$ & 0.5 & 2.5 & 0.025 & 0.5 \\
\hline $\mathrm{Hg}$ contact time, $\mu \mathrm{g} \min ^{-1}$ & 200 & 0.05 & 1.25 & 0.05 \\
\hline Sorbent temperature, ${ }^{\circ} \mathrm{C}$ & 120 & 120 & 120 & 120 \\
\hline Volume of the bed $\left(\mathrm{cm}^{3}\right)$ & 4.9 & 2.5 & 1.4 & 3.5 \\
\hline Relation fly ash:sand & $1: 3 \mathrm{w} / \mathrm{w}$ & $1: 3 \mathrm{w} / \mathrm{w}$ & $1: 3 \mathrm{v} / \mathrm{v}$ & $1: 4 \mathrm{w} / \mathrm{w}$ \\
\hline
\end{tabular}

w/w: weight/weight

v/v: volume/volume 
Table 2. Loss of ignition (LOI) and BET surface area of the fly ash samples

\begin{tabular}{l|cc}
\hline & $\begin{array}{c}\text { LOI } \\
(\mathbf{\%})\end{array}$ & $\begin{array}{c}\text { Surface area } \\
\left(\mathbf{m}^{\mathbf{2}} \mathbf{g}^{\mathbf{1}}\right)\end{array}$ \\
\hline CTA & 5.7 & 1.6 \\
CTA $>$ 150 & 22 & 4.2 \\
\hline CTSR & 7.2 & 9.4 \\
CTSR $>\mathbf{8 0}$ & 54 & 18 \\
\hline CTES & 2.0 & 1.9 \\
CTES $>\mathbf{2 0 0}$ & 18 & 13 \\
\hline CTP & 3.8 & 6.7 \\
\hline
\end{tabular}


Table 3. Mercury retention capacity and time needed to achieve equilibrium capacity in the fly ash samples for the different experimental devices

\begin{tabular}{|c|c|c|c|c|c|c|c|c|}
\hline & $\begin{array}{l}\mathrm{Hg} \mathrm{N}^{0} 1 \\
\left(\mu g \mathrm{~g}^{-1}\right) \times 10^{3}\end{array}$ & $\begin{array}{l}\mathrm{t} \\
(\min )\end{array}$ & $\begin{array}{l}\mathrm{Hg} \mathrm{N}^{\circ} 2 \\
\left(\mu g \mathrm{~g}^{-1}\right)\end{array}$ & $\begin{array}{l}\mathbf{t} \\
(\min )\end{array}$ & $\begin{array}{l}\mathrm{Hg} \mathrm{N}^{0} 3 \\
\left(\mu \mathrm{g} \mathrm{g}^{-1}\right) \times 10^{3}\end{array}$ & $t(\min )$ & $\begin{array}{l}\mathrm{Hg} \mathrm{N}^{0} 4 \\
\left(\mu \mathrm{g} \mathrm{g}^{-1}\right)\end{array}$ & $\begin{array}{l}\mathrm{t} \\
(\mathrm{min})\end{array}$ \\
\hline CTA & $0.30 \pm 0.02$ & 45 & $1.1 \pm 0.2$ & 100 & $<0.1$ & 3 & $0.80 \pm 0.20$ & 100 \\
\hline CTA $>150$ & $0.32 \pm 0.02$ & 67 & $1.0 \pm 0.2$ & 200 & $0.16 \pm 0.03$ & 100 & $1.6 \pm 0.2$ & 150 \\
\hline CTSR & $3.7 \pm 0.2$ & 102 & $16.0 \pm 1.6$ & 700 & $0.11 \pm 0.02$ & 68 & $17.3 \pm 1.7$ & 900 \\
\hline CTSR $>80$ & $3.8 \pm 0.2$ & 118 & $40.7 \pm 4.1$ & 900 & $0.37 \pm 0.02$ & 540 & $49.0 \pm 4.9^{*}$ & 1075 \\
\hline CTES & $0.11 \pm 0.01$ & 90 & $1.4 \pm 0.2$ & 100 & $<0.1$ & 3 & $0.74 \pm 0.20$ & 80 \\
\hline CTES $>200$ & $0.21 \pm 0.02$ & 80 & $1.4 \pm 0.2$ & 200 & $0.28 \pm 0.02$ & 397 & $4.5 \pm 0.5$ & 325 \\
\hline CTP & $0.57 \pm 0.02$ & 130 & $1.2 \pm 0.2$ & 125 & $<0.1$ & 3 & $1.2 \pm 0.2$ & 100 \\
\hline
\end{tabular}

*Thermodynamic equilibrium had not yet been reached 